\title{
How to Write Feminist Legal History: Some Notes on Genealogical Method, Family Law, and the Politics of the Present
}

\begin{abstract}
Ann Genovese
Genealogy does not oppose itself to history as the lofty and profound gaze of the philosopher might compare to the molelike perspective of the scholar; on the contrary, it rejects the metahistorical deployment of ideal significations and indefinite teleologies. It opposes itself to the search for 'origins'.

Michel Foucault, 'Nietzsche, Genealogy, History' $(1971)^{1}$

We are arguing for a political perspective in historical research and writing, a suggestion which must disturb every academic vigilant in pursuit of the 'value-free' ... It is only by seeking and recognizing political relevance in history that we can bring it more directly into the battle of ideas ...
\end{abstract}

Sally Alexander and Anna Davin, 'Feminist History' (1976)²

What is the purpose of feminist legal histories, and how can we write them, especially in Australia in our own times? In this essay I explore, in the spirit of dialogue, how we might confront the tension between legal history's intellectual traditions, and the political effects of law's legacies in the present. This question of method is an important inference in this collection's conversation about 'who owns the legal past'. My premise is that for many legal history projects, especially in a settler-colonial state like Australia, writing about law historically requires a conscientious identification of law's present paradoxes, discontinuities, and iterations. To this end, this chapter will be in three parts. First, a description of the historiographical problems I have encountered in my current project, which is an account of how feminism and law met in the 1970s. Second, a consideration of what genealogy as a particular theory and method for writing can offer feminist histories of the present in light of those problems;

1 Michel Foucault, 'Nietzsche, Genealogy, History', in The Foucault Reader, ed., Paul Rabinow (New York: Pantheon Books, 1984), 77.

2 Sally Alexander and Anna Davin, 'Feminist History', History Workshop 1 (Spring 1976): 6. 
and lastly, to turn to some of the questions of limits or anxieties that such an approach entails, when one of the political constituents of the present is spoken in the narratives and archives of law.

\section{Problems: Writing Australian histories of 'feminism' after 1970}

My research project on feminism and family law after 1970 aims, in a macro sense, to understand current cultural and public discourse about feminism as a historical question. Feminism, in its 1970s formations, sought to question the gendered bases of how society operated, and to imagine a different, utopian future. Now, in the twenty-first century, feminism is resented or miscast, viewed as a battle for equality that has been won, or a revolution that promised much and delivered little. My political project is to understand how so many came to see feminism in this way, and with what consequences. Making theoretical and historical sense of how feminism is understood as simultaneously a malevolent success and a malignant failure drives much current feminist scholarship. ${ }^{3}$ As Angela McRobbie, to take just one example, writes in The Aftermath of Feminism, that feminism in its post-1968 expression was a manifold 'self organised politics, taking place from the ground up, a kind of disputatious and contentious force, especially in matters of sexuality and family life', bearing enormous potential for social change. Yet that potential, she argues I think correctly, is what has also, in our own times, caused 'anxiety, concern and pre-emptive action, on the part of those bodies, institutions and organisations which do not wish to see established power and gender hierarchies undermined' ${ }^{4}$

It is difficult, however, to write about feminism's very recent past. In one sense, this is a difficulty for all historians of the late twentieth century - our 'period' is often unfathomable (even within historical scholarship itself) as 'history'. As Tony Judt has argued, this miasma about the recent past is pervasive:

The 20th Century is hardly behind us, but already its quarrels and its dogmas, its ideals and its fears, are slipping into the obscurity of mismemory. Incessantly invoked as 'lessons', they are in reality ignored and untaught. This is hardly unsurprising. The recent past is the hardest to know and understand. ${ }^{5}$

3 This is a point made by many. For an important discussion, see: Marian Sawer, 'Populism and Public Choice in Australia and Canada: Turning Equality-Seekers into "Special Interest"', in Us and Them: AntiElitism in Australia, eds, Barry Hindess and Marian Sawer (Perth: API Network, 2004), 33-56. Also see, Ann Genovese, 'Worlds Turned Upside Down', Feminist Review 95 (2010): 69-74; Margaret Henderson, Marking Feminist Times: Remembering the Longest Revolution in Australia (Bern: Peter Lang, 1996).

4 Angela McRobbie, The Aftermath of Feminism (London: Sage Publications, 2009), 2.

5 Tony Judt, Reappraisals: Reflections on the Forgotten Twentieth Century (New York: Penguin Press, 2009), 4. 
This is particularly the case when feminism (of the 1970s and 1980s) is evoked as a category of historical enquiry. Feminism in this sense is not directly interchangeable with feminist history writing. The latter has a been a key technique and practice of feminist politics since the $1970 \mathrm{~s}^{6}$ and, as Sally Alexander and Anna Davin note in the epigraph to this chapter, it challenged the certainties of method and intent of historiography in order to expose the causes and shapes of women's absence, resistance or oppression. ${ }^{7}$ The former, interrogating Australian feminism - itself a subject of feminist history - has of course played a part in that praxis. For example, Barbara Caine's history of the Victorians, ${ }^{8}$ or Marilyn Lake's work on the internationalism of the 1920 s and 1930s and beyond, ${ }^{9}$ both demonstrate how earlier 'waves' of feminism have been written about to interpolate the political and historical form and content of the writer's own times. But, maybe because of the rapidity of social change since the 1970s, or its sheer scale of impact (Agnes Heller calling 1970s feminism 'the greatest and most decisive social revolution of modernity'), ${ }^{10}$ or because those who were there are still very much present in the present, writing about feminism since the 1970s as a historical subject is often distinctively fraught. As Meaghan Morris has explained, the fact that feminism in this period occasioned social change 'while at the same time contesting the very bases of modern thinking about what constitutes "change" induced 'intense strain, almost a kind of overload, in historical articulation'. ${ }^{11}$ Margaret Henderson in Marking Feminist Times specifically explores that 'intense strain' through an Australian history of the cultural texts (film, histories, memoir, fiction) that were written by those present in the 1970s, to speak to their own unease about contemporary feminist politics. Henderson's account argues that, because present '[f]eminist cultural memory is being made in a counter-revolutionary time', ${ }^{12}$ there is tension between the historical remembrances (and mis-remembrances) produced by those who took part, and those who want to relate the archives produced by feminist groups in the 1970-90s to the manifestations of feminist disorder in the present. $^{13}$

\footnotetext{
6 See Ann Curthoys, 'Historiography and Women's Liberation', Arena 22 (1970): 35-40; Alexander and Davin.

7 See, in general, Ann Curthoys and John Docker, Is History Fiction? (Sydney: University of New South Wales Press, 2006), 154-79.

8 Barbara Caine, Victorian Feminists (Oxford University Press, 1992).

9 Of course Marilyn Lake also interpreted her own time, in the broader historical narrative. See Marilyn Lake, Getting Equal: The History of Australian Feminism (Sydney: Allen and Unwin, 1999); also see Margaret Henderson's response to Lake in Henderson, 38.

10 Agnes Heller, 'Existentialism, Alienation, Postmodernism: Cultural Movements as Vehicles of Change in Patterns of Everyday Life', in Postmodern Conditions, eds, Andrew Milner, Philip Thomson and Chris Worth (New York: Berg Publishers, 1990), quoted in Henderson, 13.

11 Meghan Morris, Too Soon Too Late: History in Popular Culture (Bloomington and Indianapolis: Indiana University Press, 1998), quoted in Henderson, 11.

12 Henderson, 14.

13 See ibid.; also see Ann Genovese, 'Writing The Past as Politics', Lilith: A Feminist History Journal 17 (2008), lilith.org.au/the-journal/lilith-17-2008/Genovese accessed September 5, 2011.
} 
Despite these difficulties, there is important critical scholarship, such as that by Henderson, Natasha Campo, or Monica Dux and Zora Simic, that determinedly makes recent Australian feminism itself the object of historical inquiry. ${ }^{14}$ This work, however, speaks through the traditions of cultural and social history. To position recent feminism as a category for legal history is a less familiar practice, entailing not only similar difficulties but also additional ones. The similarity lies in the fact that feminisms' recent engagements with and through law are usually written about in feminist legal scholarship as 'lessons' (in Judt's sense). These 'lessons' offer a means by which to compare feminist legal reform progress over the past 30 years, which tightens the bind and allure of teleological histories. ${ }^{15}$ Notably, and as a general exception in Australia, Margaret Thornton has identified and written about feminism as constitutive of legal historical narratives (for example, Dissonance and Distrust) in a way that does not overcommit to the success/failure script. ${ }^{16}$ Perhaps because of this recognition, Thornton has also suggested how hard it is, in Australian feminist legal scholarship, to think about the recent and local as anything but normalised. In her 2004 essay 'Neoliberal Melancholia', she describes this phenomena as 'myopia': the inevitable loss of ability by individuals or communities to focus on what is nearest to them. ${ }^{17} \mathrm{I}$ agree with her, but would also emphasise that this has consequences: it becomes incomprehensible to render strange or uncertain that which is accepted; and, at the same time, it becomes acceptable to 'mis-memorialise' legal feminism's immediate past in the present. Although there is a wealth of feminist legal scholarship in Australia and internationally which is committed to viewing doctrinal or theoretical developments in law through a gendered history, ${ }^{18}$ there is, with few exceptions, a reluctance to understand the part played by legal feminism's own institutional forms, and epistemic engagement with the object of its critique: the law. This is a point also made in the genealogical jurisprudence of legal scholar Maria Drakopoulou, who has argued, for example, that modern legal feminist thought is so 'fuelled by a yearning for change', by a desire to

14 Henderson; Natasha Campo, From Superwomen to Domestic Goddesses: The Rise and Fall of Feminism (Bern: Peter Lang, 2009); Monica Dux and Zora Simic, The Great Feminist Denial (Melbourne University Press, 2008).

15 See, for example, Australian Feminist Law Journal 20 (June 2004).

16 Margaret Thornton, Dissonance and Distrust: Women in the Legal Profession (Oxford University Press, 1996). I have also written to these questions, see: Genovese, 'Family Histories: John Hirst v Feminism, in the Family Court of Australia', Australian Feminist Studies 21 (2006): 173-96; Genovese, 'Madonna and/or Whore?: Feminism(s) and Public Sphere(s)', in Romancing the Tomes: Popular Culture, Law and Feminism, ed., Margaret Thornton (London; Sydney: Cavendish Publishing, 2002), 146-64. Also see Dorothy E. Chunn, Susan B. Boyd and Hester Lessard, eds, Reaction and Resistance: Feminism, Law, and Social Change (Vancouver: UBC Press, 2007), which approaches these issues from a Canadian perspective.

17 Thornton, 'Neoliberal Melancholia: The Case of Feminist Legal Scholarship', The Australian Feminist Law Journal 20 (2004): 20.

18 See Diane Kirkby, Dealing With Difference: Essays in Gender, History and Culture (Melbourne University Press, 1997); Kirkby, ed., Sex, Power and Justice: Historical Perspectives on Law in Australia (Melbourne: Oxford University Press, 1995); Rosemary Hunter, ed., Rethinking Equality Projects in Law: Feminist Challenges (Oxford: Hart Publishing, 2008). 
expose, critique and reform the 'phallocentric nature of the political, ontological and epistemological commitments' of law, ${ }^{19}$ that feminism 'necessarily registers a lack' in itself. ${ }^{20}$ Drakopoulou seeks, as a response, to understand the practice of feminist jurisprudence itself as a 'phenomena', that shifts in its formations, and which must be held to account in how it 'colours the seemingly neutral technology of reform' ${ }^{21}$

There is therefore an additional difficulty of using feminism as a category for recent legal history that is not present for social or cultural histories. To argue for a history of law that is also unsettled, or at least unsettling, because of its interactions, dominations by, or contaminations with other cultural or political ideas, is always difficult. This is because of the tendency of law to be legocentric, ${ }^{22}$ to view the only sustainable historical narratives as those that mimic law itself: common law, stages of legislative reform, legal theory, which often do not speak to the contentious archive that feminism produces. Legal history, when reflecting on or summarising what has been achieved or what has not worked as it should in terms of reform, does not relish looking outside of itself to the communities and cultural contexts with which it interacts to look for explanations. It especially does not easily view that external history as of importance to itself ${ }^{23}$ (A point to which I will return.) Feminist legal scholarship, although a branch of critical legal praxis which could potentially engage in the cultural context or 'outside' of its own traditions, is reluctant to do so if the 'outside' is the unruly yet dynamic cultural histories of Australian feminism, from where it emerged. ${ }^{24}$ As a result, feminist legal scholarship in Australia seems often unwilling to ask how, and when, 'our positions work in the same register of the political rationality ... which they purport to criticize'.$^{25}$

19 Maria Drakopoulou, 'Feminism, Governmentality and the Politics of Legal Reform', Griffith Law Review 14 , no. 1 (2008), 330.

20 ibid., 331.

21 ibid., 334.

22 I have developed this point through conversations with Patrick Wolfe, who is in turn deploying the famous quote from Alexis de Tocqueville, 'Scarcely any political question arises in the United States that is not resolved, sooner or later, into a judicial question'. Alexis de Tocqueville, Democracy in America (Ware, Hertfordshire: Wordsworth Editions Limited, 1998), 123.

23 See Robert W. Gordon, 'Introduction: J. Willard Hurst and the Common Law Tradition in American Legal Historiography', Law \& Society Review 10, no. 1 (Fall 1975): 9-56.

24 Genovese, 'A Radical Prequel: Historicising the Concept of Gendered Law in Australia', in Sex Discrimination in Uncertain Times, ed., Margaret Thornton (Canberra: ANU E Press, 2010), 47-73.

25 Wendy Brown, 'Genealogical Politics', in The Later Foucault, ed., Jeremy Moss (London: Sage Publications, 1998), 40. 


\section{Problems: Writing Australian histories of (family) 'law' after 1970}

In order to attempt to contextualise legal feminism through its episteme, I chose to explore the recent and disruptive history of Australian family law. This is not because I wish to offer an account of the reformist 'phases' of the Family Law Act (1975) Cth, to gauge if they provide signposts of legal responsiveness (or not) to a changing society. In my legal history, I have focused on family law and its archive because it has carried most transparently the story of the political responses to and incursions by feminism into law, since the late 1960s. Specifically, and in summary: The 1975 Act was intended by the state as a break with a non-cosmopolitan past, a progressive commitment to recognise people's sexual and personal freedom through a 'caring' court. This new streamlined jurisdiction, a flagship of modern Australian values and governance in many ways, was accompanied by a raft of other measures that replaced older forms of moral or economic control over families with new ones. Under the new regime of the 1970s, which involved the intersection of family law with child support, state based protections against domestic violence, welfare and tax law, families could be socially identified, protected, and prosecuted. The move to modernise Australian family relationships, however well intentioned, led to diffuse forms of scrutiny and regulation of individual men, women and children. The personal battles between individuals in court - battles read specifically through shifting social and political ideas of gendered fairness, because of the critical praxis of feminist knowers, and actors - became translated into legal doctrine, and legislative presumptions. Rights, interests, needs, and freedoms that were grounded on sexed identities began to have a legal limit. ${ }^{26} \mathrm{My}$ point is that feminisms and law in this period are not parallel but constitutive. Feminists in the 1970s and 1980s robustly debated the definition of the family in relation to the state and its premises, leading to the development of specifically feminist legal thinking and critique. ${ }^{27}$ These ideas inevitably made their way into family law reform processes. The performance and construction of legal feminisms can therefore be understood as a specific expression of what, in an American idiom, can be called Left Legalism. An outcome of lawyers' engagement with critical politics from the late 1960s, Left Legalism was intent on enabling political questions of minority groups to become legal ones. ${ }^{28}$ This is I think a phenomena

\footnotetext{
26 See Genovese, 'Family Histories'; Genovese, 'National Legislation and Transnational Feminism', in Feminist Theory \& Activism in Global Perspective: Feminist Review Conference Proceedings (2010), e99-e155.

27 For three examples: Martha Fineman, The Illusion of Equality: The Rhetoric and Reality of Divorce Reform (The University of Chicago Press, 1990); Regina Graycar and Jenny Morgan, The Hidden Gender of the Law (Sydney: Federation Press, 1990); Carol Smart, The Ties that Bind: Law, Marriage, and the Reproduction of Patriarchal Relations (London; Boston: Routledge and Kegan Paul, 1984).

28 Wendy Brown and Janet Halley, 'Introduction', in Left Legalism/Left Critique, eds, Wendy Brown and Janet Halley (Durham; London: Duke University Press, 2002), 1-37. David Kennedy makes a similar point
} 
that has also arisen in Australia, despite having a different experience, and meaning of 'legalism' itself. It is no accident, for example, that the direct confrontation of the state by Indigenous politics' over the issue of land rights, since the 1970s, has become, increasingly, a series of questions for courts, or has, at least, been read through law. The same could be said of feminist projects.

Janet Halley and Wendy Brown, respectively legal and political theorists, in their edited collection Left Legalism/Left Critique explore this phenomenon in detail. They argue that critical legal praxis took seriously the legal realist point that law is politics by other means, but never anticipated the extent to which the reverse proposition would become increasingly dominant. ${ }^{29}$ Their analysis is useful as a way of interpreting law as a historical question, and practice, in later modernity. It infers that the rise of legalism as a form of politics has meant that the particular space which was carved out by lawyers in the 1980s, lawyers who were committed to gender or sexuality based challenges to liberal legalism's traditions, has been undermined. This demands close archival attention in any feminist history of the recent past. The space for politics in law, imagined as a Trojan horse for feminists in the 1970s and 1980s, is now wide open: the ressentiment expressed by fathers' rights groups, for example, appropriates the same strategic language as the feminist groups that they critique. This renders feminist arguments those that contest law's operation on gendered grounds - as potential poisons, and as vulnerable. If they want to have any voice at all, feminists must play in the demarcated spaces set up by family law, yet they are susceptible to being denigrated as a 'femi-nazi plot' ${ }^{30}$ The problem that emerges, and the one that drives my project, is that contemporary life 'is so saturated by legalism' that it is often difficult to imagine alternative ways of deliberating feminism's response to law, or even imagining when the very rhetoric of 'equality' or 'rights' inferred a political response. Embeddedness of both feminist thinking within law, and thinking about feminism through law, make it difficult to address material or philosophical problems that are predicated in an ever shifting formulation of gender. As Brown and Halley put it:

As we incessantly refer our political life to the law, we not only sacrifice opportunities to take our inherited political condition into our own hands, we sacrifice as well the chance to address at a more fundamental or at least far reaching level various troubling conditions which appear to require address. ${ }^{31}$

about international law in the same volume: David Kennedy, 'When Renewal Repeats: Thinking against the Box', 373-419.

29 Brown and Halley, 19.

30 Genovese, 'Family Histories'.

31 Brown and Halley, 20. 
For me, therefore, 'family law' is not only a constantly contested jurisprudential and policy space, but also a history of the present. In telling this narrative, I do not seek to 'add in' histories of feminism to what John Dewar has called family law's 'normal chaos', 32 nor to reposition ideas about what or how to constitute feminist legal theory through a gendered critique of family law's operation. ${ }^{33} \mathrm{My}$ point is slightly different, although informed by those other scholarly spaces. Family law offers to my project a complex archive of later modernity, through which to expose, and consider as contingent, the effects that liberal legalism has had on feminism as a political force which set out to contest it.

\section{Genealogy, and how it matters for feminist histories of the present}

But how can we actually write a politically and culturally located feminist legal history? It is one thing to offer a summary of my argument in this context, quite another to write this story in a historical form. I want to avoid teleology as a narrative frame, as it is the telling of feminism's present as a story positioned on a 'success' or 'failure' or 'lessons' axis that is the problem. My search for an alternative approach has led me to a re-engagement with genealogy as a method for writing history of the present. As Foucauldian scholars Andrew Barry, Thomas Osborne and Nikolas Rose have argued, genealogy can be viewed as a specific method for scholarly enquiry in later modernity; it helps us to destabilise the perceived inevitability of the present and to "bring into view the historically sedimented underpinnings of particular "problematizations" that have a salience for our contemporary experience'.$^{34}$

The very idea of writing histories of the present is not only an exercise to diagnose our own times. Friedrich Nietzsche in On the Genealogy of Morality (1887) took the idea of writing of the subjective experience of knowledge as a way to destabilise the certainty of forward-looking Enlightenment projects. For example, he insisted that values experienced were not inevitable, that they served purposes that may not be immediately clear, and that they required 'deciphering', or 'artful questioning' instead of chronicling, with the aim being

\footnotetext{
32 John Dewar, 'The Normal Chaos of Family Law', Modern Law Review 61, no. 4 (July 1998): 467-85.

33 See, for example, Alison Diduck, Law's Families (London: Lexis Nexis, 2003).

34 Andrew Barry, Thomas Osborne and Nikolas Rose, 'Introduction', in Foucault and Political Reason: Liberalism, Neoliberalism and Rationalities of Government, eds, Andrew Barry, Thomas Osborne and Nikolas Rose (University of Chicago Press, 1995), 5.
} 
to reveal them as not common place, but historically contingent and variable. Nietzsche called this genealogy and described it as the way into 'a secret garden, the existence of which no one suspected'. ${ }^{35}$

These were ideas that were of course attractive to historical (and political) theorists throughout the twentieth century, including, in different ways, Benedetto Croce, and Hannah Arendt. ${ }^{36}$ But, of course, it is the scholarship of the 1970s and 1980s itself, especially that of Michel Foucault alongside feminist historians like Joan Scott, who asked contemporaneous questions about the function of gender as a category of historical analysis and knowledge, ${ }^{37}$ which grounded genealogy as a historical practice in later modernity. These scholars sought to make sense of how Enlightenment traditions constructed political subjects yet, at the same time questioned the then dominant form of liberal critique: Marxism. What Foucault, for example, did in projects like Discipline and Punish (1977) was to take Nietzsche's idea that knowledges are inherently capable of various perspectives, and Croce's idea that the historian writes out of the interests of the present, and developed them into a 'sociology of knowledge'. ${ }^{38}$ History, in these terms, became an analysis of power in the present: its deviations, ruptures, and insidiousness.

In his 1971 essay 'Nietzsche, Genealogy, History', for example, Foucault offers his account of the purpose and intent of genealogy as methodological politics and practice. He replaces the traditional search for total history the 'constants' of 'traditional history'39 with 'effective' history," 'which seeks to dispel the chimeras of origin' ${ }^{41}$ The point of this effective history is to 'introduce discontinuity into our very being' ${ }^{42}$ to show the differences and disruptions of the uncertain past and, therefore, the uncertain present. Effective history is history of the present, it 'shortens its vision to those things nearest to it ... it reverses the surreptitious practice of historians, their pretensions to examine things furthest from themselves ... It studies what is closest, but in an abrupt dispossession' ${ }^{43}$ Foucault importantly, is not speaking in this essay as an abstract philosopher: genealogy is a 'tactical weapon' not a conceptual

\footnotetext{
35 Friedrich Nietzsche, On the Genealogy of Morality (1887), ed., Keith Ansell-Pearson, trans., Carol Diethe (Cambridge University Press, 2007), 5.

36 Benedetto Croce, 'History and Chronicle' (1917), as discussed in Curthoys and Docker, 91-93, and in Hayden White, 'The Abiding Relevance of Croce's Idea of History', Journal of Modern History 37 (June 1963): 109-24; Hannah Arendt, 'The Modern Concept of History', The Review of Politics 20, no. 4 (1958): 570-90.

37 Joan Scott, Gender and Politics of History (New York: Columbia University Press, 1988); Michel Foucault, Discipline and Punish: The Birth of the Prison, trans., Alan Sheridan (London: Penguin Books, 1977).

38 Curthoys and Docker, 186.

39 Foucault, 'Nietzsche, Genealogy, History', 80.

40 ibid., 87.

41 ibid., 80.

42 ibid., 88.

43 ibid., 89
} 
construction of fixed meaning, as Mariana Valverde has described. ${ }^{44}$ Nor in turning to genealogy as a method is he suggesting in any way the substitution of material or archival engagement for wilful theoretical disturbance. On the contrary: Foucault's genealogies are always over archived: the archive rather than being a contained or linear investigation of key events, institutions or individuals, 'demands endless erudition', 45 it becomes sprawling and ever expanding, in order to expose and understand the conditions of accident and how contingencies appear. The point is that the genealogist sets out to study 'numberless beginnings whose faint traces and hints and colour are readily seen by an historical eye'. ${ }^{46}$ What Foucault offers in 'Nietzsche, Genealogy, History', and in his histories, is both a method for and performance of how to write history of the present.

Genealogy can, however, be viewed as a dangerous practice. ${ }^{47}$ It can be treacherous for the writer, as there is no road map in, or out, of the sprawling archive, (Nietzsche's 'secret garden') and the very artful questions asked at the start of an inquiry must, irresolutely, be shifted as a result. The danger is also that because by necessity genealogy speaks against the grain of the time in which it is written, the kind of knowledge that may be exposed is '[of a] kind that is not [necessarily] desired' ${ }^{48}$ Further, as Wendy Brown argues in her essay on the political intent of Foucault's genealogical method, 'Politics without Banisters' (2001), genealogy is a practice that is necessary for 'stalled' projects like feminism. Brown argues, I think rightly, that genealogies are often viewed as potential political dead ends, rather than as openings. This is because, unlike traditional political or narrative history, which desires to explain something in particular, and in which 'legitimate political positions' flow directly from their endpoint of 'objective' or 'systematic' political critiques, ${ }^{49}$ genealogies proscribe nothing. They seek no totalising transformation besides disruption of what is thought of as so normalised as to be unworthy of comment (for example: 'human rights means progress'). Yet, genealogy features instead 'forthrightly contingent elements of desire, attachment, judgment and alliance as the compositional material of political attachments and positions' ${ }^{50}$ Foucault called genealogy 'ontology of the present' and, as Brown suggests, this offers something to feminism. It is something quite different, she argues from 'ontologically grounded politics', it is instead a '[c]ritical ontology of the present [which could] be precisely what productively disrupts or "cuts" the tight relation between constructions of identity and

\footnotetext{
44 Mariana Valverde, 'Specters of Foucault in Law and Society Scholarship', American Review of Law and Society 6 (2010): 45.

45 Foucault, 'Nietzsche, Genealogy, History', 77.

46 ibid., 81.

47 Or legacy; see ibid., 82.

48 Wendy Brown, Politics out of History (Princeton; Oxford: Princeton University Press, 2001 ), 97.

49 ibid., 118-20.

50 ibid., 119.
} 
normative political claims in the contemporary political rationality ${ }^{.51}$ This is a point also made by Drakopolou, who exhorts specifically feminist legal politics to shift 'away from the relentless effort to establish links between how things are and how they ought to be ... and [to become] concerned instead with trying to identify why things are as they are and not as they were before' ${ }^{52}$ It is for this reason that history of the present offers not just a way of engaging in scholarly disorientation, or even visiting secret gardens. It is an important practice for projects like feminism, which do seem stalled, or trapped because, as a practice, an act of writing, Brown reminds us:

[G]enealogy reorients the relationship of history to political possibility: although the political possibility is constrained by its histories, those histories are themselves tales of improbable, uneven, and unsystematic emergence, and thus contain openings for disturbance. ${ }^{53}$

\section{Is genealogy intelligible to law and its history?}

But, to write history in those terms, it is necessary to consider how the contemporary political rationality is already given narrative form. And, as noted, the role law itself plays in shaping our own times cannot be gainsaid. It constitutes the political relations for a project like feminism in our present, and surreptitiously demands stories of progress, (and therefore moralising about success/failure) when attempting to write of that relation. So, the real dilemma in attempting a history of the present predicated on asking about the contingent relations between feminism and family law, is not only feminism itself, as described in the first part of this chapter, but the law: both historicising it, and at the same time making it the constitutive subject of a broader political and historical narrative.

One aspect of this dilemma is the question of whether a genealogical approach, drawn as a method from Foucault, and when used to critique law's doctrinal institutional (or in my case, cultural) presence, is recognisable within Foucault's own work on law. This is a criticism raised by Ben Golder and Peter Fitzpatrick in their recent book Foucault's Law (2009). Although there has been an important tradition developed in critical legal and sociological scholarship that uses the practices of genealogy, ${ }^{54}$ Golder and Fitzpatrick describe such scholarship (including the work of Valverde and Rose) as 'appropriative' and 'occasioning

51 ibid.

52 Drakopoulou, 'Women's Resolution of Lawes Reconsidered: Epistemic Shifts and the Emergence of the Feminist Legal Discourse', Law and Critique 11, no. 1 (2000): 71.

53 Brown, Politics, 103.

54 See, for example: Valverde, The Age of Light, Soap, and Water: Moral Reform in English Canada, 18851925 (Toronto: McClelland and Stewart, 1991); Jacques Donzelot, The Policing of Families, trans., Robert 
a certain conceptual violence to Foucault's broader arguments and critical focus' ${ }^{55}$ This is because, in their own book, they seek to assert that within Foucault's corpus of work is a discernable and conceptually whole philosophy of law. I think such assertion misjudges the purpose of Foucault's own project, as described above, as it attempts to convert 'the juridical' from practices disturbed by genealogy as constitutive of problems inherent in liberalism, into theories of philosophical completeness that mimic the Enlightenment practices that Foucault sought to render uncertain. ${ }^{56}$ But, as I align myself with these 'appropriative' scholars, who are interested in understanding genealogy as a historical practice that questions law's intent and effects, as opposed to a jurisprudence, I want to consider two problems specific to the concerns and practices of legal history, and to ask whether genealogy can in fact be intelligible to law because of those traditions.

The first, as already mentioned, is the problem of legal history's own method and intent. The dominant legal historiographical practice is what critical legal historian Robert Gordon described in 1975 as the common law tradition, in which legal history's method and intent is to justify law's teleology. ${ }^{57}$ This is regardless of whether history is invoked to write scholarly accounts of law's development, or invoked judicially to make sense of what is empirically questionable in the experience of those who stand outside the law. This is important to question, in all nation states, where the archives that enable this 'legal history' are, in a spirit true to Ranke and to Hegel, those of the institutions of the state itself, especially the courts. Such archives, and the teleologies of national progress that they assume and produce, are of particular concern to legal historians in settler colonies like Australia and New Zealand. We only need to re-read, for example, the cumulative judgements in the Yorta Yorta decision, or even Mabo (which used history to expose terra nullius, yet to sidestep sovereignty), to see how that works in practice. ${ }^{58}$ What is absent from such traditional legal histories, histories that law both creates and can recognise, is their conscious challenge to law: they offer no room for alternative accounts of law, or a more open past. Genealogies of law, by contrast, openly challenge and contradict that tradition as they aim to distort the inevitability of the history of law itself. To make a case for genealogies as histories of the present where law's own authority and function is not contained or certain in its legitimacy, opens the very real possibility that

Hurley (New York: Pantheon Books, 1979); Carol Smart, Feminism and the Power of Law (London; New York: Routledge, 1989); Jeffrey Minson, Genealogies of Morals: Nietzsche, Foucault, Donzelot and the Eccentricity of Ethics (New York: St Martin's Press, 1985).

55 Ben Golder and Peter Fitzpatrick, Foucault's Law (New York: Routledge, 2009).

56 Valverde argues that Golder and Fitzpatrick are trying to 'recuperate Foucault for the grand European philosophical tradition within which Heidegger looms large': Valverde, 'Specters', 45.

57 Gordon, 'Introduction'.

58 For commentary on Gordon's thesis in the Australian context, as well as these cases, see Ann Curthoys, Ann Genovese and Alexander Reilly, Rights and Redemption (Sydney: University of New South Wales Press, 2008), 140-43 and Chapters Two and Three, which discuss the Mabo and Yorta Yorta decisions respectively. 
one of the intended audiences for such histories - the community of law, as opposed to the community of which law is a part - can be dismissive of, or deaf to, the political intent and challenge.

The second, interrelated problem, is that of narrative. This concerns how genealogical interrogations that are intended to destabilise the present can ever account for law while, at the same time, trying to suggest law's current function in our society has escaped its boundaries. That is, law becomes the site of critique of minority rights politics but, at the same stroke, is exposed as a means by which those groups must endeavour to contest their subjecthood. Historicising law as a response to present political conditions means unsettling law's origins, yet also potentially acquiescing to law's role in liberal societies. This is hard to write, as Gordon noted presciently in 1980s, as:

[making an historical case about] the fundamentally constitutive character of legal relations in social life is a lot easier to understand [and research] when made about slave or feudal societies than about liberal societies, as in liberal societies differences of legal status are not supposed to define social relationships, but merely to channel and facilitate them. ${ }^{59}$

Writing this story becomes increasingly difficult the closer we are to our own times, again, as already noted in relation to histories of feminism. Legal historians are always implicated in law: as both critics and participants, in ways we cannot always choose. The writing of law as a constitutive rather than isolated part of a general history of later modernity means the legal historian, if engaged in genealogy, can unsettle the very narratives they inhabit, potentially leaving their projects exposed as irrelevant to the triumphalism of law's progress.

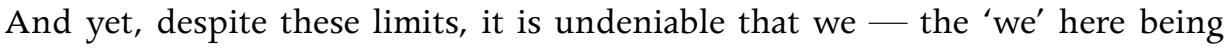
those of us who gather to write and research legal history, have as a discipline sought to meet the challenges we make. The opening up of legal history as a field of enquiry or critique that enables a different understanding of what law does in culture and society, to whom, and how, was, like feminism and legalism, also possible because of the philosophical and historical turns of modernity itself. Legal history as practice is therefore also produced by the conditions I seek to understand, and has as a result become difficult to describe and contain. It is no longer the handmaiden to precedent, the provenance of Frederick Maitland's enclosed legal scholar. ${ }^{60}$ It has prised open the back of the common law's ticking clock, most importantly — as already noted — in work concerned with understanding law's implications in the settler-colonial

59 Robert W. Gordon, 'Critical Legal Histories', Stanford Law Review 36, no. 1/2 (January 1984): 104.

60 Frederick William Maitland, Essays on the Teaching of English History (Cambridge University Press, 1901). 
project. ${ }^{61}$ Despite the suspicion of many jurists, the political nature of much historical writing about law's violence over indigenous peoples, as well as their resort to its protections, has exposed a contingent nature of law, and produced significant political rethinking. Regardless of what other historical work we do, for many, if not most, legal historians in settler-colonial states in the present, myself included, there is a constant questioning of what laws must or can mean, that is never separated from the interrogation of dispossession. This does not eradicate the internal pull of law's own promises, but the political question of injustice and Aboriginal people has made us work harder to cut another tight relation between constructions of legal history and law itself, as genealogy suggests we might.

To conclude: I think legal history as a practice must bring these insights to bear on all work that questions the nation state in various guises. The epistemological step in relation to settler-indigenous histories and the law demands nothing less: that is the paradigmatic example of how law operates, not its exception, and as such it suggests possibilities for perspectives that unsettle the effects legalism has had on minority politics. Although we need to be vigilant about our own traditions, I want to be optimistic that the political questions and practices, including those embodied by legal feminism, that seem normalised, underexposed or resisted can be understood as adventitious and also situated. How to write a legal history in which feminism operates as category and as a political question is, then, to descend into the sprawling archives of both the cultural politics of feminism, and its constitutive response in domestic law, and to make visible how it is implicated and embedded in complex national as well as disciplinary pasts. I have predicated my 'legal history' on political pamphlets as well as cabinet documents relating to the writing of legislation; I have conducted oral histories with feminist activists as well as judges; I have read the letters of an earlier generation of father advocates alongside the 'canon' of women's liberation literature. The point is that the narratives that are opened by this uncertain archive may infer contingent possibilities for feminisms, as well as vary our understanding of law, in the unsettling contemporary moment. Genealogy's value, as Foucault said, is as a 'curative' or 'antidote' to the poisons of its own time, ${ }^{62}$ and this is something that ought to resonate with legal historians today as we 'discover that truth or being does not lie at the root of what we know and what we are, but the exteriority of accidents' ${ }^{63}$

61 For example: Shaunnagh Dorsett, 'Mapping Territories', in Jurisprudence of Jurisdiction, ed., Shaun McVeigh (Oxford: Routledge-Cavendish, 2007), 137-58; Julie Evans, Edward Eyre, Race and Colonial Governance (Dunedin: Otago University Press, 2005); Paul McHugh, Aboriginal Societies and the Common Law: A History of Sovereignty, Status and Land (Oxford University Press, 2004); Lisa Ford, Settler Sovereignty: Jurisdiction and Indigenous People in America and Australia, 1788-1836 (Cambridge, Mass: Harvard University Press, 2010).

62 Foucault, 'Nietzsche, Genealogy, History', 90.

63 ibid., 81. 